Berkala Ilmu Perpustakaan dan Informasi, Vol. 14, No. 2, Desember 2018, Hal. 124-132 DOI: 10.22146/bip.32247

ISSN 1693-7740 (Print), ISSN 2477-0361 (Online)

Tersedia online di https://jurnal.ugm.ac.id/bip

\title{
Analisis business model canvas pada perpustakaan Institut Bisnis dan Informatika Stikom Surabaya dalam meningkatkan kualitas perguruan tinggi
}

\author{
Ayouvi Poerna Wardhanie ${ }^{1}$ dan Deasy Kumalawati ${ }^{1}$ \\ ${ }^{1}$ Fakultas Teknologi dan Informatika, Institut Bisnis dan Informatika Stikom Surabaya \\ Email : ayouvi@stikom.edu
}

Naskah diterima: 12 Januari 2018, direvisi: 8 Juni 2018, disetujui: 9 Juli 2018

\begin{abstract}
ABSTRAK
Pendahuluan. Penelitian ini dilakukan dengan tujuan untuk menganalisis bisnis model canvas yang telah dilakukan oleh Perpustakaan Stikom Surabaya dengan menggunakan sembilan elemen bisnis model canvas yaitu customer segments, value proposition, channels, customer relationship, revenue streams, key resources, keyactivities, key partnership, dan cost structure.

Metode penelitian. Bersifat deskriptif kualitatif, untuk mencari informasi faktual yang detail tentang masalah atau praktik yang terjadi di lapangan.

Hasil dan Pembahasan. Berdasarkan pengamatan, hasil analisa menunjukkan bahwa seluruh sivitas akademika dan masyarakat umum dapat dilayani. Value yang ditawarkan yaitu layanan berbasis teknologi dan kenyamanan pengunjung. Channel yang disediakan ialah website, email, media sosial dan keberadaan staf, Hubungan yang dibangun adalah Personal Assistance dan Self Service. Perpustakaan Stikom Surabaya tidak memiliki sumber penghasilan sendiri karena merupakan organisasi non profit perguruan tinggi. Sumber daya kuncinya manusia, teknologi dan fasilitas. Aktivitas kuncinya yakni penyedia learning commons, Mitra bisnisnya terdiri atas mitra internal maupun eksternal, Biaya yang dikeluarkan cenderung value driven di mana fokus pada pemberian pelayanan premium.

Kesimpulan dan Saran. Perpustakaan Stikom Surabaya ingin mewujudkan visinya sebagai learning commons dan pusat informasi yang unggul dan berkualitas, dengan menyediakan saluran informasi dan komunikasi yang lengkap, cepat dan mudah sesuai dengan perkembangan teknologi dan kebutuhan customer segments.
\end{abstract}

Kata Kunci: Model Bisnis Canvas; Perpustakaan; Kualitas.

\section{ABSTRACT}

Introduction. This study aims to analyze the business model canvas by the Library of Stikom Surabaya by using nine elements. They are customer segments, value propositions, channels, customer relationships, revenue streams, key resources, key activities, key partnerships, dan cost structure.

Data Collection Method. The study used qualitative descriptive perspective to examine factual information and emerging practices in the field.

Results and Discussions. Students, staff and community should be able to leverage the library services. The value offered was technology-based services and visitor convenience. Channels provided were the library website, email, social media. Customer relationships were built through personal assistance and self service. The key resources were human, technology and facilities. The key activities were learning commons. The key partnerships were internal and external partners.

Conclusions. The Library is committed to realising its vision as a superior information center by providing a complete and fast information and communication channel in accordance with technological developments and customerneeds.

Keywords: Business Model Canvas; Library; Quality. 


\section{A. PENDAhuluan}

Setiap organisasi terkadang berhadapan dengan keharusan untuk melakukan perubahan dengan cepat dan dramatis guna menghadapi lingkungan yang juga berubah, salah satu yang terkena dampak dalam perubahan organisasi tersebut perpustakaan. Saat ini, semua organisasi baik itu yang bersifat profit oriented maupun non-profit oriented membutuhkan sentuhan bisnis dalam mempertahankan eksistensi dan menjaga hubungan dengan pelanggannya. Keberadaan sebuah perpustakaan menjadi faktor penentu kemajuan sebuah universitas, terlepas dari banyaknya pendapat tentang perpustakaan, kita sadari atau tidak, perpustakaan merupakan bagian kegiatan belajar mengajar di perguruan tinggi. Perpustakaan perguruan tinggi benar-benar menjadi sarana pembelajaran yang bermanfaat bagi mahasiswa untuk memperoleh wawasan yang lebih luas. Perpustakaan perguruan tinggi sering juga diibaratkan sebagai jantungnya sebuah perguruan tinggi (the heart of university) (Mubasyaroh, 2016).

Berdasarkan Undang-Undang Nomor. 43 tahun 2007 tentang perpustakaan, menjelaskan bahwa fungsi perpustakaan adalah sebagai wahana pendidikan, penelitian, pelestarian, informasi dan rekreasi untuk meningkatkan kecerdasan dan keberdayaan bangsa. Menurut (Mursyid, 2015) pemahaman tentang fungsi perpustakaan masih belum mengakar kuat di benak dan budaya masyarakat khususnya di Indonesia. Akibatnya, perpustakaan masih saja dijadikan sebagai gudang untuk menumpuk buku dan pelengkap akreditasi institusi belaka, bahkan lebih parahnya lagi hanya dijadikan sebagai tempat pembuangan orang yang bermasalah dan orang-orang yang memang tidak memiliki kompetensi di bidang perpustakaan.

Peran perpustakaan di era teknologi saat ini, mayoritas dikuasai oleh sebuah generasi yang sering kita kenal dengan generasi millennial. Perpustakaan dimotori oleh pustakawan dituntut untuk lebih proaktif dan inovatif dalam memberikan layanan informasi yang dibutuhkan pemustaka, yakni generasi millenial. Perpustakaan menyediakan layanan memperhatikan tingkat efisiensi dan efektifitas waktu, guna menghasilkan tingkat kepuasan konsumen yang tinggi. Era digital merupakan sebuah tantangan bagi beberapa organisasi, salah satunya perpustakaan, karena kegiatan yang dilakukan harus didukung dan melibatkan teknologi, sehingga mau tidak mau, suka tidak suka perpustakaan harus bermetamorfosa dan mengikuti segala perkembangan dalam teknologi. Di sinilah peran pustakawan dibutuhkan, pustakawan tidak hanya bertugas dalam penataan, pengumpulan dan segala bentuk administrasi tentang buku tetapi juga memiliki wawasan dan ide kreatif dalam pemanfaatan teknologi untuk memajukan perpustakaan dalam transisi perpustakaan manual ke perpustakaan otomasi yang kemudian menuju perpustakaan digital (Junaeti \& Arwani, 2016).

Upaya menciptakan peluang usaha khususnya di perpustakaan Institut Bisnis dan Informatika Stikom Surabaya dilakukan agar mampu menarik lebih banyak pengunjung dalam memanfaatkan fasilitas yang disediakan oleh perpustakaan. Untuk itu diperlukan sebuah inovasi model bisnis bagaimana perpustakaan dapat menciptakan, memberikan, dan menangkap nilai bagi organisasi itu sendiri, pelanggan dan masyarakat. Dalam buku yang diterbitkan oleh (Tim PPM Manajemen, 2012) yang berjudul "Business Model Canvas: Penerapan di Indonesia" terdapat 9 elemen dasar yang memperhatikan bagaimana cara berfikir suatu organisasi baik itu profit maupun non profit seperti perpustakaan dalam meningkatkan kualitas layanan perpustakaan di dalam sebuah perguruan tinggi, serta dapat menghasilkan nilai dan menciptakan manfaat bagi para pelanggannya. Elemen-elemen tersebut meliputi Customer Segment, Value Propositions, Channel, Customer Relationship, Revenue Streams, Key Activities, Key Partnership, Key Resources dan Cost Structure (Permana, 2013).

Berdasarkan latar belakang di atas, penelitian tentang Analisis Bisnis Model Canvas pada perpustakaan sebuah perguruan tinggi sebagai organisasi nirlaba sangat diperlukan karena keberadaannya sebagai salah 
satu faktor penentu kemajuan suatu universitas. Selain itu pada penelitian-penelitian sebelumnya belum ada penelitian yang membahas tentang Analisis Bisnis Model Canvas pada sebuah perpustakaan di perguruan tinggi. Sejauh ini Bisnis Model Canvas banyak digunakan pada perusahaan atau organisasi profit oriented, seperti contohnya pada penelitian (Gunawan, 2016) berjudul Perancangan Business Model Canvas sebagai Alternatif Strategi Bisnis Budidaya Ikan Gurame (Studi kasus pada UKM Mitra Mina, Desa Sridadi, Kecamatan Kalirejo, Lampung Tengah). Siregar \& Fitria (2016) meneliti dengan judul Analisis Bisnis Model dengan Pendakatan Business Model Canvas terhadap Usaha Mikro Agribisnis. Permana (2013) meneliti dengan judul Analisis Peluang Bisnis Media Cetak melalui Pendekatan Bisnis Model Canvas untuk Menentukan Strategi Bisnis Baru. Serta Adhitya \& Eka (2016) meneliti dengan judul Analisis Model Bisnis Pada Bisnis Sepatu Guten. Inc Menggunakan Model Bisnis Kanvas.

\section{B. TINJAUAN PUSTAKA}

\section{Business Model Canvas}

Kepopuleran konsep model bisnis di mulai sejak tahun 1990 ke atas ketika internet mulai banyak membahas tentang konteks model bisnis dalam sebuah perusahaan dan bagaimana perubahan lingkungan bisnis. Konsep model bisnis digunakan sebagai cara yang umum untuk menjelaskan bagaimana perusahaan berinteraksi dengan pemasok, mitra kerja, dan pelanggan, serta untuk menggambarkan dasar pemikiran tentang bagaimana organisasi menciptakan, memberikan, dan menangkap nilai (Gunawan, 2016). Buku yang berjudul "Business Model Generation" (Osterwalder \& Pigneur, 2010) membuat suatu kerangka business model yang berbentuk kanvas dan terdiri dari sembilan kotak yang saling berkaitan. Kotak-kotak ini berisikan elemenelemen penting yang menggambarkan bagaimana organisasi menciptakan nilai dan mendapatkan manfaat dari para pelanggannya. Penjelasan kesembilan kotak tersebut menurut (Wardhanie, 2017) antara lain : a. Customer Segments adalah masyarakat yang menggunakan jasa/produk dari organisasi dan mereka yang berkontribusi dalam memberikan penghasilan bagi organisasi. Segmentasi pelanggan juga dapat dipilah berdasarkan perilaku, umur, profesi, penghasilan dan geografi.

b. Value Propositions merupakan satu keunikan yang menentukan mengapa produk atau jasa tersebut pantas dipilih oleh pelanggan. Hal ini memberi tawaran untuk memecahkan masalah pelanggan dan semaksimal mungkin memenuhi keinginan pelanggan.

c. Channel, sebuah elemen seperti komunikasi, distribusi dan saluran penjualan yang menyatakan bagaimana cara organisasi berkomunikasi dengan pelanggan segmennya dan menyampaikan value proposition-nya.

d. Customer Relationship, pembinaan hubungan dengan pelanggan, dengan tujuan untuk mendapatkan pelanggan baru dan mempertahankan pelanggan lama.

e. Revenue Streams atau aliran dana masuk yang menggambarkan bagaimana organisasi memperoleh penghasilan berupa uang dari setiap customer segments. Aliran dana inilah yang membuat sebuah perusahaan tetap hidup atau survive.

f. Key Resources menggambarkan aset-aset terpenting yang menentukan keberhasilan pengoperasian model bisnis, seperti bangunan, kendaraan, intelektual dan tenaga kerja.

g. Key Activities merupakan kegiatan utama yang menunjang keberhasilan suatu model bisnis dalam mengirimkan value propotitions-nya kepada pelanggan.

h. Key Partnership, suatu kesepakatan kerja sama bisnis yang diprakarsai secara sukarela antara dua atau lebih perusahaan untuk menyelesaikan proyek tertentu. Kerjasama ini dapat menimbulkan penghematan biaya, mengurangi resiko dan memperoleh sumber daya yang tidak dimiliki perusahaan.

$i$. Cost Structure menggambarkan semua biaya yang muncul sebagai akibat 
dioperasikannya model bisnis ini guna mewujudkan value propotitions melalui channel, key resource, key activities yang tepat dan dapat diandalkan.

\section{Perpustakaan}

Peran dan fungsi sebuah perpuskaan di beberapa lembaga, seperti di tingkat pusat maupun daerah serta lembaga pemerintah dan swasta sangat berbeda. Masyarakat pun kini telah mengenal berbagai macam jenis-jenis perpustakaan, diantaranya yakni perpustakaan nasional, perpustakaan daerah, perpustakaan perguruan tinggi, perpustakaan sekolah, perpustakaan khusus, dan perpustakaan masjid atau tempat ibadah lainnya. Adapun definisi dari sebuah perpustakaan itu sendiri ialah suatu unit kerja sebuah lembaga atau badan yang memberikan pelayanan informasi maupun mengelola bahan-bahan pustaka, baik berupa buku-buku maupun bukan berupa buku (non book material) yang diatur secara sistematis menurut aturan tertentu sehingga dapat digunakan sebagai sumber informasi oleh setiap pemakainya (Mubasyaroh, 2016). Dari sekian banyak jenis perpustakaan yang ada di Indonesia, perpustakaan di sebuah perguruan tinggi berperan sangat krusial dalam dunia pendidikan. Adapun fungsi perpustakaan khususnya di perguruan tinggi adalah sebagai fungsi edukatif, fungsi informasi, fungsi riset, fungsi rekreasi, fungsi publikasi dan fungsi deposit untuk seluruh karya dan pengetahuan yang dihasilkan oleh warga perguruan tingginya (Rismayeti, 2013). Kaitannya dengan mutu pendidikan maka manajemen perpustakaan berada pada mutu proses yaitu bagaimana kemampuan lembaga pendidikan dalam mendayagunakan sarana sumber belajar perpustakaan secara optimal untuk mendukung proses pembelajaran.

Kualitas sebuah perpustakaan tidak bisa dijelaskan secara mutlak karena tergantung dari beberapa hal yaitu (1) Mutu input sebuah perpustakaan yang meliputi ketrampilan dam kecakapan pustakawan dan pengelola di dalamnya. (2) Mutu proses di dalam sebuah perpustakaan yang meliputi mutu proses pemberian layanan kepada pengunjung, mutu dalam pengelolaan koleksi bahan pustaka yang up to date, mutu dalam penggunaan teknologi sehingga proses pencarian dan penelusuran sebuah informasi dapat dilakukan dengan cepat dan efektif, mutu dalam menjalin hubungan baik dengan masyarakat dan lembaga. (3) Mutu luaran, yakni penyediaan layanan yang berkualitas dan penyediaan koleksi-koleksi bahan pustaka yang bermutu dan menunjang proses pembelajaran sivitas akademikanya (Benawi, 2013).

\section{Keberadaan Perpustakaan di Perguruan Tinggi}

Pada dasarnya perpustakaan perguruan tinggi merupakan upaya untuk memelihara dan meningkatkan efisiensi dan efektifitas proses belajar-mengajar antara dosen dengan mahasiswa, mahasiswa dengan mahasiswa, ataupun alumni dan masyarakat umum (Anggorowati \& Widayati, 2017). Perpustakaan yang sudah dikelola secara sistematis dan diorganisir dengan baik oleh manajemen perpustakaan, secara langsung ataupun tidak langsung dapat memberikan kemudahan bagi proses belajar-mengajar. Oleh sebab itu, terkait dengan kemajuan dalam bidang pendidikan dan adanya perbaikan metode belajar-mengajar yang dirasakan, tidak bisa dipisahkan dari masalah penyediaan fasilitas pembelajaran dan informasi pendukung. Biasanya fasilitas pendukung pembelajaran tersebut disediakan oleh lembaga perpustakaan, seperti koleksi buku terbaru, katalog jurnal nasional maupun internasional, bahkan penyediaan software seperti Turnitin atau Plagscan. Merujuk pada pandangan tersebut, maka pengadaan perpustakaan di lembaga pendidikan termasuk perguruan tinggi merupakan sebuah keharusan (Rizki, 2013). Perpustakaan perguruan tinggi merupakan salah satu jenis perpustakaan yang paling mudah diidentifikasi sebab, pada umumnya setiap perguruan tinggi memiliki perpustakaan yang dikelola secara khusus dan ditempatkan secara khusus sehingga dapat dibedakan dari lembaga atau unit-unit lainnya yang berada di lingkungan kampus perguruan tinggi. Adapun tujuan diselenggarakannya perpustakaan di perguruan tinggi yaitu untuk 
mendukung, memperlancar serta meningkatkan kualitas pelaksanaan program kegiatan belajar mengajar di perguruan tinggi melalui pelayanan informasi yang meliputi aspek-aspek pengumpulan informasi, pengolahan informasi, pemanfaatan informasi, dan penyebarluasan informasi (Azmar, 2015).

\section{METODE PENELITIAN}

Penelitian ini menggunakan metode deskriptif dengan pendekatan kualitatif, yakni menjelaskan dan menggambarkan secara mendalam tentang situasi atau proses yang diteliti yaitu perpustakaan (Rakhmat, 2007). Informan kunci dalam penelitian ini adalah Kepala Bagian Perpustakaan dan Staf Pengembangan dan Pemanfaatan TI. Selain itu peneliti juga mengambil data sekunder melalui website perpustakaan. Analisis data bersifat induktif kualitatif dan hasil dari penelitian ini bertujuan untuk mencari informasi faktual yang detail mengenai gejala yang ada dalam perpustakaan, mengidentifikasi masalah masalah yang terjadi dan praktik - praktik yang sedang berlangsung dengan melakukan wawancara mendalam terhadap subyek penelitian sehingga dapat memberikan gambaran yang jelas mengenai penerapan business model canvas pada Perpustakaan Institut Bisnis dan Informatika Stikom Surabaya.

\section{HASIL DAN PEMBAHASAN}

Tantangan terbesar dalam sebuah organisasi yakni dapat mendesain sebuah model bisnis yang baru dan inovatif. Perpustakaan melakukan hal tersebut perlu adanya sebuah penelitian yang dapat menghasilkan sebuah data-data terbaru yang nantinya dapat digunakan untuk pengambilan keputusan. Oleh sebab itu, peneliti melakukan penelitian ini dengan cara pengumpulan data secara observasi, wawancara dan dokumentasi untuk membuat business model pada Perpustakaan Institut Bisnis dan Informatika Stikom Surabaya dengan bantuan business model canvas yang terdiri dari 9 elemen berikut ini :

\section{Customer Segments}

Perpustakaan Stikom Surabaya merupakan salah satu unit yang bertanggung jawab dalam menyediakan segala sumber informasi dan pencarian literatur bagi masyarakat dan khususnya sivitas akademik Stikom Surabaya. Adapun customer segments yang dilayani oleh Perpustakaan Stikom Surabaya antara lain, semua mahasiswa Stikom dengan status aktif, dosen (dosen tetap, dosen luar biasa, asisten dosen dan co-asisten laboratorium) yang berstatus aktif, semua alumni Stikom Surabaya yang memiliki kartu identitas alumni, serta anggota baca yang meliputi masyarakat umum, mahasiwa dari perguruan tinggi lain, pelajar atau karyawan dari sebuah instansi yang ingin mengembangkan diri dan meningkatkan wawasan melalui koleksi dan fasilitas di Perpustakaan Stikom Surabaya.

\section{Value Propositions}

Nilai yang ditawarkan oleh Perpustakaan Stikom Surabaya sebagai salah satu perpustakaan perguruan tinggi dengan akreditasi A sebagai berikut:

\section{a. Performance}

- Layanan Repository yang bernama SIR (Stikom Institusional Repository) merupakan sebuah aplikasi yang menyediakan akses pencarian untuk semua koleksi karya ilmiah untuk mendukung proses belajar mengajar baik di dalam internal Stikom Surabaya maupun di lingkungan eksternal yaitu masyarakat luas.

- Perpustakaan Stikom Surabaya memiliki kartu yang bernama Kartu Super, yaitu sebuah kartu yang digunakan untuk mengakses segala layanan dan fasilitas bahan puskata yang disediakan oleh seluruh perpustakaan yang tergabung dalam FPPTI Jawa Timur, sehingga dengan adanya kartu ini pemustaka tidak perlu lagi untuk mengurus surat izin ke masing-masing perpustakaan anggota FPPTI jika ingin menggunakan layanan tersebut. 


\section{b. Accessibility}

- Kemudahan dalam mengakses online catalog.

- Kemudahan dalam mencari koleksi terbaru yang meliputi buku, majalah, jurnal, software, dan tugas akhir.

- Membuka website Perpustakaan Stikom Surabaya dapat terhubung dengan pencarian dokumen-dokumen yang sudah terformat digital, seperti bank soal ujian tengah semester maupun akhir semester dari tahun ke tahun, modul pembelajaran dosen seluruh fakultas, prosiding/jurnal, video dan audio yang terkait pembelajaran serta materi tentang orientasi kegiatan kemahasiswaan bagi mahasiswa baru, yang mana semua hal itu terangkum dalam fitur E-Resource Center.

\section{c. Convenience}

- Tersedianya loker untuk meletakan barang bawaan pengunjung sehingga tidak mengganggu saat pencarian bahan pustaka.

- Akses internet gratis menggunakan WiFi yang bisa diakses melalui perangkat mobile seperti laptop, PDA, atau PC yang dilengkapi dengan teknologi WiFi.

- ILT (Integrated Learning Terminal) yaitu sebuah layanan pendukung kegiatan belajar mengajar baik secara hard skill maupun soft skill seluruh sivitas akademika Stikom Surabaya. Dalam penyelenggaraan fasilitas ILT ini, perpustakaan Stikom Surabaya memiliki 18 unit komputer yang dapat mengakses internet secara gratis, antara lain Digital Library dan koleksi $E$ Resources seperti Jurnal, E-Book, MP3 dan sebagainya, dapat mengunduh artikel untuk menunjang kegiatan pembelajaran misalnya untuk materi perkuliahan dan tugas-tugas kuliah, serta mengakses koleks E-Resources Center dan koleksi digital lainnya.

\section{Channels}

Dalam meyampaikan value proposition-nya kepada para customer segments, Perpustakaan Stikom Surabaya menggunakan website yang dapat diakses di http://library.stikom.edu/ask-alibrarian.html di mana terdapat fasilitas seperti live chat sehingga pengunjung bisa langsung berbicara dengan staf perpustakaan, email dengan alamat perpus@stikom.edu, layanan telephone di nomor 031- 318721731 ext. 711. Staf Perpustakaan Stikom Surabaya juga akan menerima dengan terbuka seluruh pertanyaan dari pengunjung yang datang langsung ke perpustakaan terkait tentang seputar informasi umum, pustaka, kebutuhan penelitian, studi banding antar lembaga dan lain sebagainya. Jadwal pelayanan di Perpustakaan Stikom Surabaya yaitu hari Senin - Jumat pukul 07.00 19.00 dan Sabtu pukul 07.00-12.00 WIB, serta pengunjung dapat mem-follow media sosial Perpustakaan Stikom Surabaya seperti Twitter, Instagram dan Facebook.

\section{Customer Relationship}

Jenis hubungan yang dibangun oleh Perpustakaan Stikom Surabaya dengan customer segments-nya adalah dengan hubungan Personal Assistance, yaitu pola hubungan didasarkan pada interaksi manusia. Komunikasi yang dilakukan tidak hanya sekedar bertatap muka tetapi juga dapat melalui telepon, e-mail, online chat dalam website dan media sosial yang dimiliki Perpustakaan. Selain itu, Perpustakaan Stikom Surabaya telah menyediakan self service dalam hal peminjaman produk (buku, majalah, jurnal, CD, karya ilmiah dan ruangan) secara mandiri. Dalam rangka untuk lebih melibatkan user (dalam hal ini adalah mahasiswa dan dosen) dalam penciptaan nilai atau manfaat, Perpustakaan Stikom Surabaya juga melakukan co-creation dengan cara mahasiswa bebas meminjam dan mendesain ruangan dan fasilitas yang disediakan oleh perpustakaan untuk kegiatan seperti pameran, seminar dan workshop. 


\section{Revenue Streams}

Perpustakaan Stikom Surabaya sebagai salah satu perpustakaan perguruan tinggi memiliki tujuan untuk membantu mengurangi ketidakpastian kebutuhan informasi para pemustaka dengan menyediakan informasi yang tepat, untuk menunjang kegiatan pendidikan dan penelitian (Setiawan, 2017). Revenue streams untuk sebuah organisasi nirlaba seperti Perpustakaan Stikom Surabaya tidak menggunakan tolak ukur berbentuk uang, tetapi lebih kepada pengembangan koleksi bahan pustaka berupa kontribusi pemberian buku dari calon wisudawan. Selain itu, juga berupa citra positif dari pemustaka terhadap layanan dan fasilitas yang disediakan oleh perpustakan.

\section{Key Resources}

Sumber daya kunci yang terdapat pada Perpustakaan Stikom Surabaya dibagi menjadi tiga yaitu:

a. Manusia, yang terdiri atas 8 orang staf perpustakaan dengan tanggung jawab masing-masing seperti Kepala Bagian, Pelaksana Pengembangan dan Pemanfaataan TI, Pelaksana Layanan Informasi dan Pengembangan Otomasi Perpustakaan, Pelaksana Pengolahan Koleksi Bahan Pustaka, Pelaksana Pengembangan dan Pemanfatan Perpustakaan, Pelaksana Pengembangan Koleksi Bahan Pustaka, Pelaksana Layanan Sirkulasi dan Administrasi Umum.

b. Fasilitas, terdiri dari komputer katalog, informasi koleksi terbaru (fisik koleksi yang dipasang pada papan koleksi, database koleksi dan bibliografi koleksi baru), layanan loker barang, gedung dan ruang baca.

c. Teknologi, terdiri dari e-resource center, repository, website, otomasi perpustakaan (Sistem Informasi Perpustakaan) dan RFID (Radio Frequency Identification)

\section{KeyActivities}

Serangkaian kegiatan yang dilakukan oleh

Perpustakaan Stikom Surabaya untuk menciptakan produk atau jasa yang dibutuhkan pelanggan antara lain : a. Pengadaan kebutuhan bahan pustaka. Seluruh data bahan pustaka yang telah terkumpul, baik itu dari penawaran toko buku dan penerbit, usulan dosen, mahasiswa, dan karyawan, data dari internet, selanjutnya akan dipilih dan disesuaikan dengan kebutuhan proses belajar mengajar di Stikom Surabaya.

b. Pengolahan bahan pustaka dengan cara mendaftarkan koleksi yang akan diolah ke dalam aplikasi pengadaan. Setelah bahan pustaka selesai diolah dilakukan distribusi koleksi bahan pustaka tersebut kepada user.

c. Penyediaan area beserta fasilitas untuk menunjang akademik mahasiswa dan dosen (Learning Commons).

d. Layanan informasi kepada user tentang produk dan jasa perpustakaan.

e. Pengembangan Sumber Daya Manusia Perpustakaan seperti mengikuti workshop, seminar dan menjadi anggota Forum Perpustakaan Perguruan Tinggi (FPPTI) se Jawa Timur.

\section{Key Partnership}

Tidak ada organisasi yang dapat berjalan tanpa bekerja sama dengan pihak lain, begitu juga dengan Perpustakaan Stikom Surabaya, adapun mitra kunci secara internal dari perpustakaan adalah Lembaga Perguruan Tinggi Institut Bisnis dan Informatika Stikom Surabaya, sedangkan mitra kunci secara eksternal adalah FPPTI, Badan Perpustakaan dan Arsip, Perpustakaan Nasional, Perpustakaan Perguruan Tinggi lain seperti di UNAIR, Wijaya Kusuma, STIESIA dan Universitas Petra Surabaya.

\section{Cost Structure}

Dalam mewujudkan visinya menjadi perpustakaan learning commons dan sumber segala informasi yang up to date dan berkualitas, perpustakaan Stikom Surabaya membutuhkan biaya-biaya seperti pembelian koleksi bahan pustaka, pengembangan SDM, kegiatan promosi perpustakaan dan investasi kebutuhan perpustakaan. Dalam model bisnisnya Perpustakaan Stikom Surabaya menekankan pada value driven, yakni efisiensi 
biaya tidak menjadi pertimbangan utama, tetapi sasaran utamanya adalah memberi kepuasan kepada pelanggan dengan memberi pelayanan prima.

\section{E. KESIMPULAN}

Berdasarkan hasil pengamatan business model canvas di Perpustakaan Institut Bisnis dan Stikom Surabaya maka dapat ditarik kesimpulan bahwa perpustakaan Stikom Surabaya memiliki visi sebagai learning commons dan pusat informasi yang unggul dan berkualitas, dengan menyediakan saluran informasi dan komunikasi yang lengkap, cepat dan mudah sesuai dengan perkembangan teknologi dan kebutuhan customer segments. Kegiatan utama yang dilakukan dalam mewujudkan visinya tersebut dengan meningkatkan koleksi bahan pustaka sesuai dengan kebutuhan dan perkembangan ilmu pengetahuan, meningkatkan fungsi ruang dan fasilitas guna menunjang akademik mahasiswa dan dosen serta meningkatkan pelayanan prima dalam kemudahan mengakses informasi akan produk dan jasa perpustakaan. Customer segments yang dilayani oleh Perpustakaan Stikom Surabaya antara lain, semua mahasiswa Stikom dengan status aktif, dosen (dosen tetap, dosen luar biasa, asisten dosen dan co-asisten laboratorium) yang mendapatkan jadwal mengajar dan berstatus aktif, semua alumni Stikom Surabaya yang memiliki fasilitas kartu alumni. Jenis hubungan yang dibangun oleh Perpustakaan Stikom Surabaya dengan customer segments-nya adalah dengan hubungan Personal Assistance, yaitu pola hubungan didasarkan pada interaksi manusia. Sumber daya kunci yang dimiliki oleh perpustakaan yakni pustakawan, komputer katalog dan e-resource center. Mitra kunci terdiri dari dua yaitu internal dan eksternal. Biaya yang dibutuhkan terdiri dari pembelian koleksi bahan pustaka, pengembangan SDM, kegiatan promosi perpustakaan dan investasi kebutuhan perpustakaan.

\section{DAFTAR PUSTAKA}

Adhitya, D., \& Eka, M. (2016). Analisis model bisnis pada bisnis sepatu Guten.inc menggunakan bisnis model kanvas. Jurnal Sosioteknologi, 15(3),323-334.

Anggorowati, D. N., \& Widayati, R. W. (2017). Peran forum pustakawan dalam pengembangan profesionalisme pustakawan di lingkungan Universitas Gadjah Mada. Berkala Ilmu Perpustakaan dan Informasi, 13(2),117-130.

Azmar, N. J. (2015). Peran pustakawan dalam meningkatkan kualitas layanan di perpustakaan. Jurnal Iqra, 9(2), 223-234.

Benawi, I. (2013). Peningkatan kualitas perpustakaan perguruan tinggi. Jurnal Iqra, $7(1), 42-57$.

Gunawan, M. F. (2016). Perancanagan business model canvas sebagai alternatif strategi bisnis budidaya ikan gurame (studi kasus pada ukm mitra mina desa Sridadi kecamatan Kalirejo Lampung Tengah). dilihat 1 Juni 2018. Retrieved from Http://digilib.unila.ac.id/21790/20/skripsi $\% 20$ tanpa\%20bab\%20pembahasan.pdf.

Junaeti, \& Arwani, A. (2016). Peranan perpustakaan dalam meningkatkan kualitas peguruan tinggi (konstruksi pelayanan, strategi, dan citra perpustakaan). Libraria, $4(1), 27-54$

Mubasyaroh. (2016). Pengaruh perpustakaan bagi peningkatan mutu pendidikan perguruan tinggi. Libraria, 4(1),77-104.

Mursyid, M. (2015). Pustakawan dan media massa: Dari interaksi ke dokumentasi. Yogyakarta: Ladang kata.

Osterwalder, \& Pigneur. (2010). Business model generation: A handbook for visionaries, game changers, and challengers. Hoboken, New Jersey: John Wiley \& Sons, Inc.

Permana, D. J. (2013). Analisis peluang bisnis media cetak melalui pendekatan bisnis model canvas untuk menentukan strategi bisnis baru. Faktor exacta ISSN: 1979276X, 6(4), 309-319. 
Rakhmat. (2007). Metode penelitian komunikasi. Bandung: PT. Remaja rosdakarya.

Rismayeti. (2013). Perpustakaan perguruan tinggi: pedoman, pengelolaan dan standardisasi. Jurnal Ilmu Budaya, 9(2), 104-117.

Rizki, J. W. (2013). Optimalisasi fungsi perpustakaan perguruan tinggi melalui peran pustakawan. Al-Kuttab, 1(2),105-117.

Setiawan, M. V. (2017). Mengurangi kecemasan pemustaka dalam proses penelusuran informasi melalui layanan virtual referensi di perpustakaan perguruan tinggi. Berkala Ilmu Perpustakaan dan Informasi, 13(2), 178-190.
Siregar, Z. H., \& Fitria, S. E. (2016). Analisis bisnis model dengan pendekatan business model canvas terhadap usaha mikro agribisnis keramat bey berry ciwidey. Eproceeding of management, 3(1),222-227.

Tim PPM Manajemen. (2012). Business model canvas : Penerapan di Indonesia. Jakarta: PPM.

Wardhanie, A. P. (2017). Buku ajar model bisnis. Surabaya: PT. Revka petra media. 